\title{
Novel cetacean morbillivirus in a rare Fraser's dolphin (Lagenodelphis hosei) stranding from Maui, Hawai'i
}

\author{
Kristi L. West ${ }^{1,2 \bowtie}$, Ilse Silva-Krott ${ }^{1}$, Nelmarie Landrau-Giovannetti ${ }^{3}$, Dave Rotstein ${ }^{4}$, \\ Jeremiah Saliki ${ }^{5}$, Stephen Raverty ${ }^{6}$, Ole Nielsen 7 , Vsevolod L. Popov ${ }^{8}$, Nicole Davis ${ }^{9}$, \\ William A. Walker ${ }^{10}$, Kuttichantran Subramaniam ${ }^{3} \&$ Thomas B. Waltzek $^{3}$
}

Cetacean morbillivirus (CeMV) is a global threat to cetaceans. We report a novel morbillivirus from a Fraser's dolphin (Lagenodelphis hosei) that stranded in Maui, Hawaii in 2018 that is dissimilar to the beaked whale morbillivirus previously identified from Hawaii and to other CeMV strains. Histopathological findings included intranuclear inclusions in bile duct epithelium, lymphoid depletion, rare syncytial cells and non-suppurative meningitis. Cerebellum and lung tissue homogenates were inoculated onto Vero.DogSLAMtag cells for virus isolation and cytopathic effects were observed, resulting in the formation of multinucleated giant cells (i.e., syncytia). Transmission electron microscopy of infected cell cultures also revealed syncytial cells with intracytoplasmic and intranuclear inclusions of viral nucleocapsids, consistent with the ultrastructure of a morbillivirus. Samples of the cerebellum, lung, liver, spleen and lymph nodes were positive for morbillivirus using a reverse transcription-polymerase chain reaction. The resulting $559 \mathrm{bp} L$ gene sequence had the highest nucleotide identity (77.3\%) to porpoise morbillivirus from Northern Ireland and the Netherlands. The resulting 248 bp $P$ gene had the highest nucleotide identity to porpoise morbillivirus in Northern Ireland and the Netherlands and to a stranded Guiana dolphin (Sotalia guianensis) in Brazil (66.9\%). As Fraser's dolphins are a pelagic species that infrequently strand, a novel strain of CeMV may be circulating in the central Pacific that could have additional population impacts through transmission to other small island-associated cetacean species.

Cetacean morbillivirus (CeMV) of the family Paramyxoviridae and the genus Morbillivirus, has been associated with lethal outbreaks worldwide and represents one of the greatest infectious disease threats to cetaceans. Three strains of CeMV are well recognized, including the first description of porpoise morbillivirus (PMV) in two harbor porpoises (Phocoena phocoena) $)^{1}$, dolphin morbillivirus (DMV) that was identified for the first time from striped dolphins (Stenella coeruleoalba) ${ }^{2}$ and pilot whale morbillivirus (PWMV) that was initially identified from a long-finned pilot whale (Globicephala melas) ${ }^{3}$. More recently, three other strains of CeMV have been described, two from the Southern Hemisphere (Western Australia and Brazil) and the beaked whale morbillivirus (BWMV) from Hawaii ${ }^{4-6}$. These six strains have been clustered into two lineages; the CeMV-1 lineage that includes DMV, PMV, PWMV and BWMV and the CeMV-2 lineage that is represented by the two Southern hemisphere strains?. One of the CeMV-2 strains was first described in two Indo-Pacific bottlenose dolphins (Tursiops aduncus) from Western Australia ${ }^{5}$ and was later believed to be a major contributor to an unusual mortality event in Southern

\footnotetext{
${ }^{1}$ Hawai'i Institute of Marine Biology, University of Hawai'i at Manoa, Kaneohe, HI, USA. ${ }^{2}$ Human Nutrition Food and Animal Sciences, College of Tropical Agriculture and Human Resources, University of Hawai'i at Manoa, Honolulu, HI, USA. '3epartment of Infectious Diseases and Immunology, College of Veterinary Medicine, University of Florida, Gainesville, FL, USA. ${ }^{4}$ Marine Mammal Pathology Services, Olney, MD, USA. ${ }^{5}$ Oklahoma Animal Disease Diagnostic Laboratory, College of Veterinary Medicine, Oklahoma State University, Stillwater, OK, USA. ${ }^{6}$ Animal Health Center, British Columbia Ministry of Agriculture, Abbotsford, BC, Canada. ${ }^{7}$ Department of Fisheries and Oceans Canada, Winnipeg, MB, Canada. ${ }^{8}$ Department of Pathology, The University of Texas Medical Branch, Galveston, TX, USA. 'P Pacific Islands Regional Office, National Marine Fisheries Service, Honolulu, HI, USA. ${ }^{10}$ Marine Mammal Laboratory, National Marine Fisheries Service, Seattle, WA, USA. ${ }^{\square}$ email: kristiw@ hawaii.edu
} 


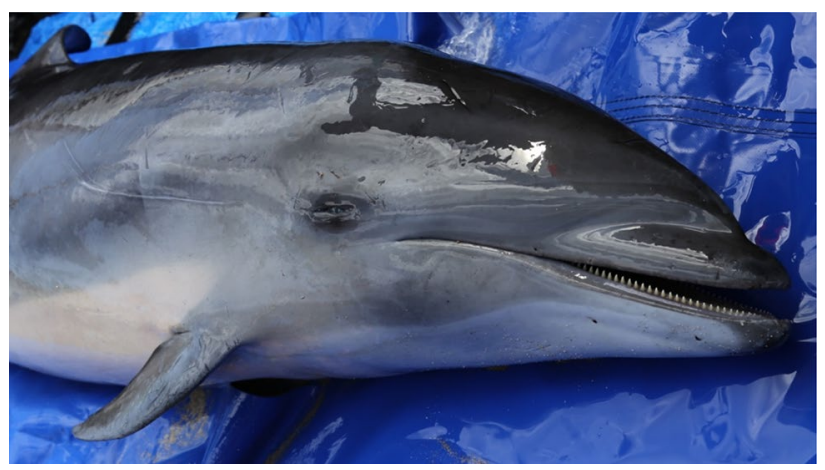

Figure 1. The sub-adult male Fraser's dolphin (Lagenodelphis hosei) that stranded at Olowalu, Maui, Hawaii. Photo courtesy of Cindy Kern.

Australia Indo-Pacific bottlenose dolphins in 2013 where CeMV nucleotide similarity was $99.7 \%$ when compared to the CeMV strain initially described from Western Australia ${ }^{8}$. The other novel Southern hemisphere CeMV-2 strain was first described from a Guiana dolphin (Sotalia guianensis) in Brazil ${ }^{4}$. The Guiana dolphin cetacean morbillivirus (GDMV) was later linked to an unusual mortality event in Brazil where over 200 Guiana dolphins $\operatorname{died}^{9}$ and most recently a CeMV identified in 3 stranded Southern right whales (Eubalaena australis) in Brazil appeared to be similar to GDMV ${ }^{10}$.

In Hawaiian waters, the BWMV strain identified in a Longman's beaked whale (Indopacetus pacificus) that stranded in 2010 off of Maui, Hawaii, represented the first report of CeMV in the central Pacific ${ }^{6}$. A retrospective screening of archived tissues from Pacific Island stranded cetaceans found the presence of BWMV in 12 different cetacean species, but no Fraser's dolphins were represented among the 18 cetacean species tested. The retrospective study indicated $24 \%$ prevalence of BWMV in at least one tissue by polymerase chain reaction (PCR) in fresh carcasses although in many cases accompanying pathology was not observed ${ }^{11}$. Full genome sequencing of the BWMV identified from Hawaii confirms that BWMV represents a separate strain of CeMV among the CeMV-1 lineage ${ }^{12}$.

Understanding the threat posed by CeMV to Hawaiian cetaceans is critical as many species represent small, island associated populations where a morbillivirus outbreak could be devastating. The present study describes a novel morbillivirus from a stranded Fraser's dolphin in Hawaii that was dissimilar when the partial sequence was compared to the RNA-dependent RNA polymerase ( $L$ gene) and phosphoprotein $(P$ gene) sequences of other morbillivirus strains. Strandings of Fraser's dolphins in Hawaii are rare with few reports of this species close to shore ${ }^{13-15}$

\section{Results}

Prey identification was conducted for the stranded Fraser's dolphin. Stomach contents included 13 lower beaks from cephalopods and a small piece of green fishing line (approximately $31 \mathrm{~mm}$ in length). The 13 lower beaks represented five different species from four cephalopod families. The family Histioteuthidae represented the greatest contribution to diet of this individual, with $53.8 \%$ contribution to diet by abundance and $74 \%$ by mass. The family Mastigoteuthidae contributed $23.1 \%$ by abundance to the diet and $13 \%$ by mass. Other cephalopod families identified among the stomach contents included Enoploteuthidae and Neoteuthidae which contributed less than $10 \%$ by prey abundance and by prey mass.

The stranded dolphin was in good body condition, had a total body length of $2.04 \mathrm{~m}$, weighed $183.5 \mathrm{~kg}$ and was an immature male (Fig. 1). Gross necropsy findings included cookie cutter shark bites and abrasions up to $30 \mathrm{~cm}$ in length along the lateral sides of the body that are likely associated with coming across reef or rocks during the stranding event. Multiple abrasions were also documented on the dorsal fluke surface. The left eye was intact, but a bleeding open wound was observed near the medial canthus that may have been due to bird scavenging of the carcass prior to recovery. A minimum of six small crustacean parasites (whale lice) were observed near the blowhole opening. The deeper blubber was bruised extending from the left cranial to the axillary region with moderate hemorrhage observed at the blubber-muscular interface. The left lung weighed $1188 \mathrm{~g}$ and the right lung weighed $1292 \mathrm{~g}$. The lungs had a mottled surface, with areas of consolidation $(1-2 \mathrm{~cm}$ in diameter) (Fig. 2A). Areas of consolidation revealed dark red to tan firm tissue around small bronchi in cross-section. The left lung marginal lymph node was enlarged and had an irregular surface. The trachea and main bronchi contained small amounts of red-tinged foam. Serous membranes in the thorax and abdomen were unremarkable. The liver weighed $2155 \mathrm{~g}$ and an enhanced lobular pattern was observed on cut surface. The spinal fluid was blood-tinged, and meningeal blood vessels were dilated.

Histopathology findings and initial diagnostics. Histopathological findings of note were observed in the lymph nodes, spleen, brain, lung and liver. Lymphocytes and plasma cells (non-suppurative inflammation) were sprinkled within the meninges and cerebral blood vessels exhibited mild lymphocytic cuffing (Fig. 2B,C). Rare syncytial cells were observed in alveoli intermixed with erythrocytes, macrophages and scant proteinaceous fluid. Pulmonary blood vessels were dilated (Fig. 2D). The liver had scattered periportal hepatocellular necrosis 


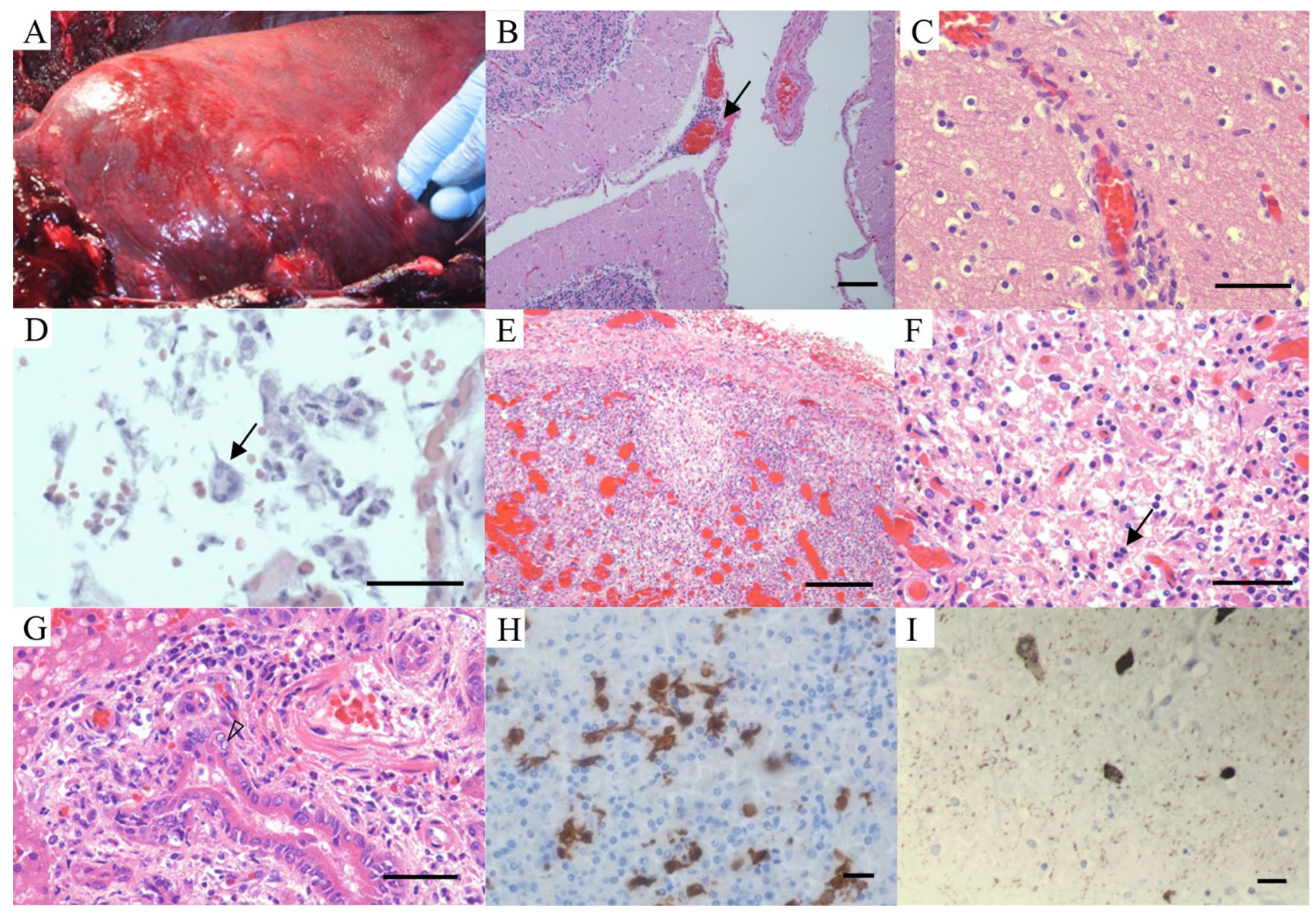

Figure 2. (A) Left lung. There are firm nodules present throughout the pulmonary parenchyma. The nodules may also be related to parasitism; (B) Meninges. H\&E stain: Lymphocytic infiltrates within the meninges (arrow). Bar $=100 \mu \mathrm{m}$; (C) Cerebrum. H\&E stain: Perivascular lymphocytic cuffing. Bar =2 mm; (D) Lung. H\&E stain: Alveolar spaces contain sloughed Type II pneumocytes, erythrocytes and rare syncytial cells (arrow). Vessels are congested. Bar $=500 \mu \mathrm{m} ;(\mathbf{E})$ Lymph node. H\& E stain: Lymphoid follicle depletion. Bar $=2 \mathrm{~mm}$; (F) Lymph node. H\&E stain: Germinal center necrosis. Syncytium (arrow). Bar $=500 \mu \mathrm{m}$; (G) Bile duct. H\&E stain: Portal hepatitis with biliary hyperplasia and viral nuclear inclusions in biliary epithelial cells (arrow head) Bar $=500 \mu \mathrm{m}$; (H) Lymph node. Morbillivirus immunohistochemical stain. Bar $=20 \mu \mathrm{m}$; (I) Brain. Morbillivirus immunohistochemical stain: Immunoreactivity within neuronal perikarya. Bar $=500 \mu \mathrm{m}$;

and portal tract expansion with moderate hyperplasia of bile ducts and small mixed inflammatory infiltrates were observed. Lymphoid organs were depleted and there was germinal center necrosis with macrophages and syncytial cells present (Fig. 2E,F). Bile duct epithelial cells had occasional large clear nuclei with faint eosinophilic intranuclear inclusions (Fig. 2G).

Immunohistochemistry. Morbilliviral antigen was detected in the cerebrum, cerebellum, spleen, lung, kidney and lymph nodes (Table 1). Immunoreactivity was observed in lymphocytes and macrophages within lymph nodes (Fig. 2H) and the spleen; in neurons and glial cells in the brain (Fig. 2I); pneumocytes, bronchial mucosal epithelial cells, macrophages and syncytial cells in the lung; and tubular epithelial cells in the kidney. Staining was diffuse and intense. Staining was intracytoplasmic and intranuclear.

Morbillivirus isolation. Vero.DogSLAMtag cells were chosen to attempt virus isolation of CeMV from cerebrum, cerebellum, right and left lungs, left hilar lymph node, mediastinal lymph node, retroperitoneal lymph node and mesenteric lymph node tissues that were collected from the stranded Fraser's dolphin. Seven days post infection no cytopathic effect (CPE) was observed and the flasks were passaged at a ratio of 1-5 but $24 \mathrm{~h}$ later small plaques developed in the flasks inoculated with both A and B samples of cerebellum (Fig. 3a,b). Plaques contained many multinucleated giant cells or syncytia, a finding consistent with morbillivirus infection. Over the next few days, similar foci developed in both right and left lung flasks. This effect could be duplicated with dilution (1:500), filtration through a 0.45 micron filter and passage onto fresh cells. No cytopathic effect was seen in flasks from the other samples including the cell controls.

Transmission electron microscopy. In ultrathin sections of infected Vero.DogSLAMtag monolayers giant cells with multiple nuclei (syncytia) were often observed (Fig. 4A). Most times their surface was "foamy" 


\begin{tabular}{|l|l|l|l|}
\hline Tissue Type: & $\begin{array}{l}\text { Morbillivirus } \\
\text { (IHC) }\end{array}$ & $\begin{array}{l}\text { Morbillivirus } \\
\text { (RT-PCR) }\end{array}$ & $\begin{array}{l}\text { Morbillivirus } \\
\text { (Isolation) }\end{array}$ \\
\hline Cerebrum & Positive & - & Negative \\
\hline Cerebellum & Positive & Positive & Positive \\
\hline Spleen & Positive & Positive & - \\
\hline Liver & - & Positive & - \\
\hline R. Lung & - & - & Positive \\
\hline L. Lung & Positive & Positive & Positive \\
\hline Kidney & Positive & - & - \\
\hline L. hilar lymph node & - & Positive & Negative \\
\hline Mediastinal lymph node & - & Positive & - \\
\hline R. pre-scapular lymph node & - & Positive & - \\
\hline Mesenteric lymph node & Positive & - & Negative \\
\hline Retroperitoneal lymph node & - & - & Negative \\
\hline Unidentified lymph node 1 & Positive & - & - \\
\hline Unidentified lymph node 2 & Positive & - & - \\
\hline Unidentified lymph node 3 & Positive & - & - \\
\hline
\end{tabular}

Table 1. Fraser dolphin tissue types tested for the presence of morbillivirus where (-) indicates that the tissue type was not examined.

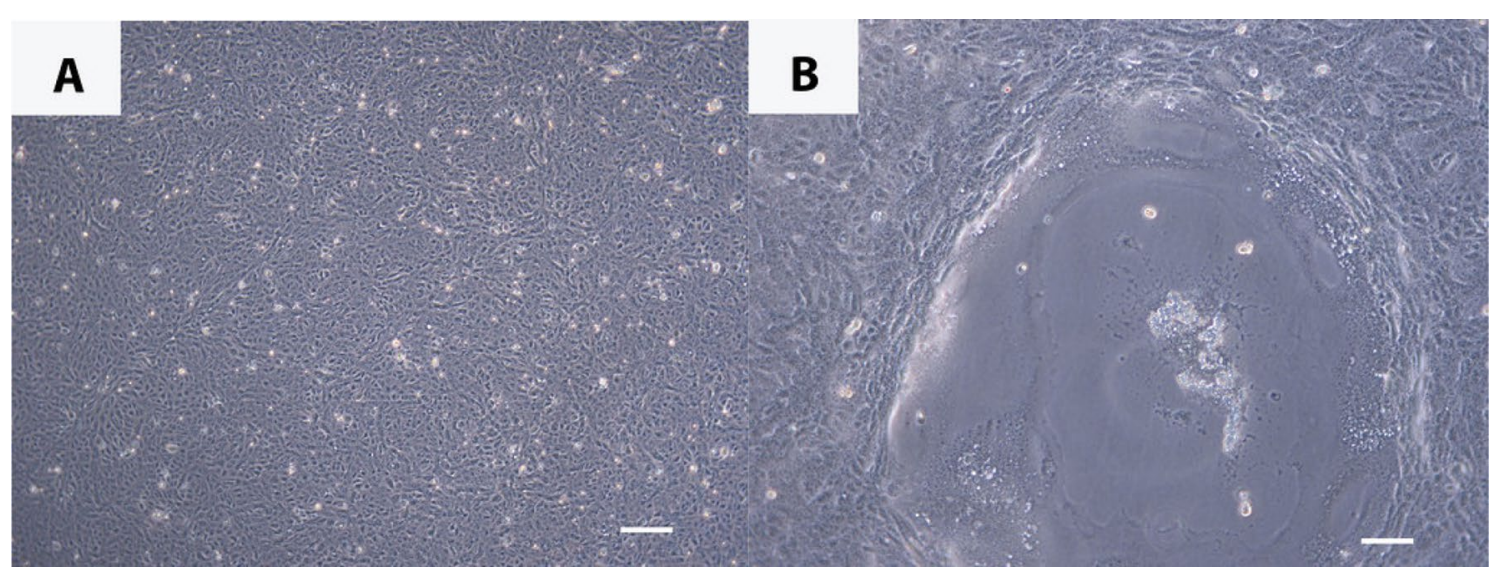

Figure 3. (A) Vero.DogSLAMtag control cells. Bar $=200 \mu \mathrm{m}$; (B) Vero.DogSLAMtag infected with Fraser's dolphin cerebellum 8 days post infection showing large syncytium. Bar $=200 \mu \mathrm{m}$.

with multiple projections of cell membrane forming "vacuoles" (Fig. 4A). Those syncytia often contained cytoplasmic inclusions of viral nucleocapsids (Fig. $4 \mathrm{~A}$ ) consisting of intertwined strands $\sim 20 \mathrm{~nm}$ in diameter (Fig. 4B), also suggestive of morbillivirus infection. At later time points of infection, those inclusions could be observed at the cell membrane but budding of the virus into the extracellular space in attached or free-floating cells was not observed. At later stages of infection intranuclear inclusions of viral nucleocapsids were regularly observed (Fig. 4C,D).

Morbillivirus detection by RT-PCR. Positive tissues by RT-PCR included the cerebellum, spleen, liver, left lung, mediastinal lymph node, right pre-scapular lymph node and the left hilar lymph node (Table 1). The partial $L$ gene sequence (559 bp) and partial $P$ gene sequence $(248 \mathrm{bp}$ ) obtained from the Fraser's dolphin were compared with $L$ gene and $P$ gene sequences of other morbilliviruses using the Sequence Demarcation Tool v1.2 ${ }^{16}$, with the MAFFT alignment option implemented (Fig. 5). The partial $L$ gene sequence of the Fraser's dolphin morbillivirus displayed highest nucleotide identity (77.3\%) to a PMV from harbor porpoises that stranded on the coast of Northern Ireland in $1988^{17}$ and in the Dutch Waddensea (North Sea-Netherlands) in $1990^{18}$. The partial $P$ gene displayed highest nucleotide identity (66.9\%) to a PMV from one harbor porpoise that stranded on the coast of Northern Ireland in $1988{ }^{17}$, two that stranded in the Dutch Waddensea (North Sea-Netherlands) in $1990^{18}$ and from a 2017 mass die-off of Guiana dolphins in Brazil ${ }^{9}$. 


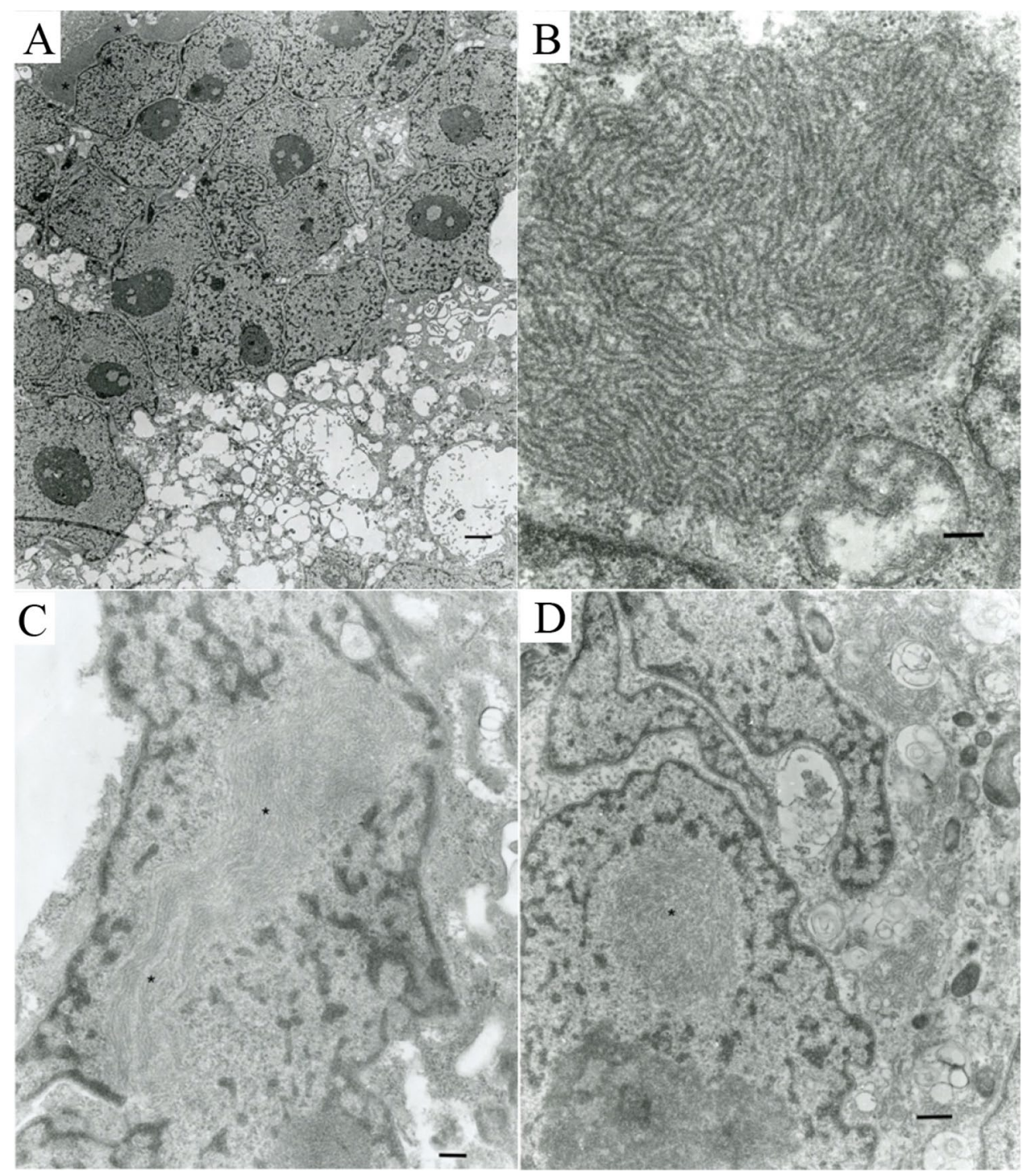

Figure 4. (A) A portion of a syncytium with multiple nuclei and a morbillivirus nucleocapsid cytosolic inclusion (upper left corner, asterisk). The surface of the monolayer (bottom) looks "foamy" due to multiple projections of plasmalemma forming multiple "vacuoles'. Bar $=2 \mu \mathrm{m}$; (B) A fragment of intracytosolic nucleocapsid inclusion with multiple (spiral) strands $\sim 20 \mathrm{~nm}$ in diameter. A portion of the nucleus is in the left lower corner. Bar $=200 \mathrm{~nm}$; (C) Large intranuclear inclusion of morbillivirus nucleocapsid (asterisk) in an attached cell in the monolayer 7 days post-infection (dpi). Bar $=200 \mathrm{~nm}$; (D) Intranuclear inclusion of nucleocapsid in a syncytium (asterisk). Portions of two other nuclei at the top of an infected one. Attached cells 7 dpi. Bar $=500 \mathrm{~nm}$.

\section{Discussion}

This rare Fraser's dolphin stranding provides insight into the biology and ecology of a poorly known species in the central Pacific. This is the first report of Fraser's dolphin diet composition in Hawaiian waters where only cephalopod prey remains were present among the stomach contents. In other regions, including the Eastern Tropical Pacific, Taiwan and the Philippines, Fraser's dolphin diet of mesopelagic fishes, cephalopods and crustaceans has been described ${ }^{19-22}$. It could be argued that the diet described from a single stranded individual may not reflect normal feeding behavior. However, there is considerable overlap in the mesopelagic taxa of cephalopods observed in the stomach of the Hawaii individual and the Fraser's dolphins from the Philippines and Taiwan ${ }^{[19.22]}$ leading us to believe that this sample is, at least in part, representative of the diet of Fraser's dolphins inhabiting the central Pacific.

The major significance of this Fraser's dolphin stranding is the discovery of a novel CeMV in Hawaiian waters that we have described as Fraser's dolphin morbillivirus. The lesions documented in multiple body systems were subacute and death may have possibly resulted from neurologic and hepatic dysfunction. Although non-specific, gross and histopathological findings are consistent with morbillivirus infection in cetaceans ${ }^{23}$ including lymphoid depletion and syncytial cells in the lung and lymph node. Viral inclusions were observed solely in the bile duct 


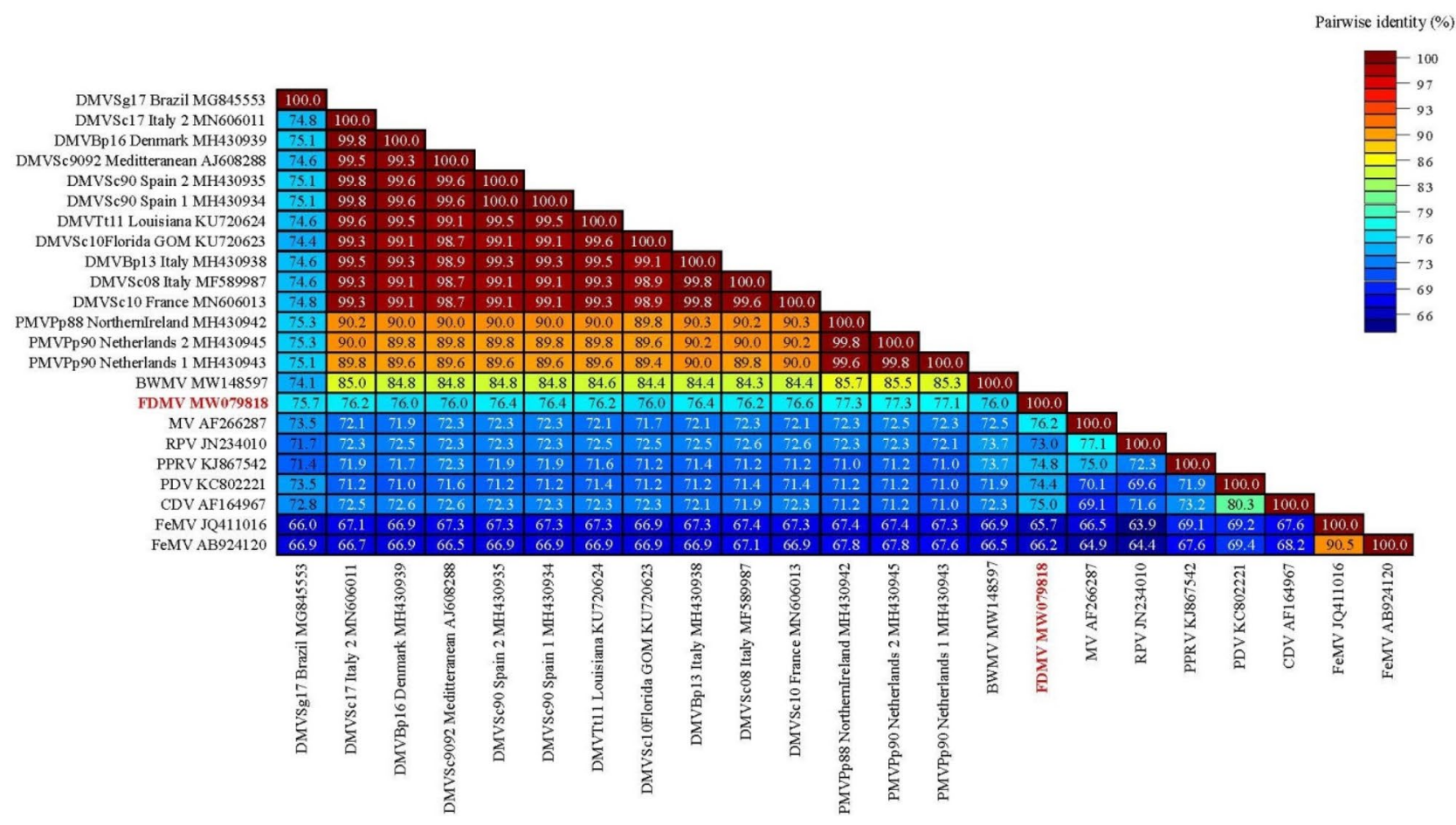

Figure 5. Genetic analysis of 23 partial nucleotide sequences of the $L$ gene. The final data set contained 559 characters including gaps. Values are expressed as a percentage of identity. $B W M V$ beaked whale morbillivirus; $F D M V$ Fraser's dolphin morbillivirus, $P W M V$ pilot whale morbillivirus; $P M V$ porpoise morbillivirus; GDMV Guiana dolphin morbillivirus; $D M V$ dolphin morbillivirus; $M e V$ measles virus; $R P V$ rinderpest virus; $P P R V$ peste-des-petits-ruminants virus; $P D V$ phocine distemper virus; $C D V$ canine distemper virus; FeMV feline morbillivirus.

epithelium. Eosinophilic intranuclear inclusions in bile duct epithelia are described in morbillivirus infection of striped dolphins and were seen in this case ${ }^{24}$. Morbillivirus-associated non-suppurative meningoencephalitis was observed without neuronal changes; however, neurons exhibited immunoreactivity with immunohistochemical stains (Fig. 2I). Co-infection or secondary infection with other viral, bacterial, protozoal, and fungal pathogens are common with CeMV infections and can also contribute to death ${ }^{25}$. A stranded neonate sperm whale that stranded on Oahu in 2011 was co-infected with Brucella and morbillivirus ${ }^{26}$. A Longman's beaked whale stranded in Maui in 2010 diagnosed with CeMV was tri-infected with an alphaherpesvirus and a novel circovirus ${ }^{6,27}$. Brucella, Toxoplasma gondii and herpesvirus were not detected during an intial diagnostic screen of this individual.

The partial sequences from both genes of the Fraser's dolphin morbillivirus was surprisingly divergent from the sequences of the six known strains of $\mathrm{CeMV}^{7}$ and suggests that the Fraser's dolphin morbillivirus is distinct (Fig. 5, 6, 7 and Table 2). Despite being described from Hawaiian waters, the nucleotide dissimilarity between the Fraser's dolphin morbillivirus and the BWMV previously described in 12 species of cetaceans from Hawaii was considerable ${ }^{6,11}$. The partial Fraser's dolphin morbillivirus $L$ gene sequence only indicated $76 \%$ similarity when compared to BWMV ${ }^{12}$. The partial $P$ gene of the Fraser's dolphin morbillivirus was also relatively dissimilar to the Southern Hemisphere CeMV strain from Brazil indicating nucleotide similarity of only $66.5 \%$ and $66.9 \%$ to Brazil ${ }^{12}$. The only $L$ gene sequence data for the Southern Hemisphere was a Brazilian strain (GenBank Accession No. MG845553) that indicated a 75.7\% nucleotide similarity. Even the highest nucleotide identity of 77.3\% between morbillivirus sequences from the Fraser's dolphin and the harbor porpoise in Northern Ireland and the Netherlands is lower than initial comparisons between the BWMV described in Hawaiian waters and the recognized DMV, PMV and PMMV strains at the time of discovery of morbillivirus in the central Pacific (83.9-88.7\% nucleotide similarity depending on $P$ or $N$ gene comparisons $)^{6,11}$. Although we only determined the partial $L$ gene $(\sim 559 \mathrm{bp})$ and $P$ gene sequences $(248 \mathrm{bp})$, our results suggest the presence of a novel morbillivirus in Hawaiian waters could be circulating in Fraser's dolphins in the central Pacific. These findings emphasize the importance of full genome sequencing of the novel Fraser's dolphin morbillivirus which is currently underway to address how this compares with other known strains of CeMV.

Despite our repeated TEM studies, we never observed the Fraser's dolphin morbillivirus budding into the extracellular spaces in vitro. This is in contrast to other morbilliviruses that bud into extracellular spaces, making it possible for virus transmission of complete virions by aerosol transmission ${ }^{34}$. Since complete virus particles were never seen, we hypothesize that virus transmission between Fraser's dolphins may occur via the aerosolizing of infected syncytial cells coming in direct cell to cell contact with a susceptible new host. Cell to cell transmission by syncytia within the same host has been documented in measles infections ${ }^{35}$.

Fraser's dolphins are a pelagic species that is poorly known from the world's oceans. There are no previous reports of morbillivirus in Fraser's dolphins from Hawaiian waters. In the greater United States seronegative 


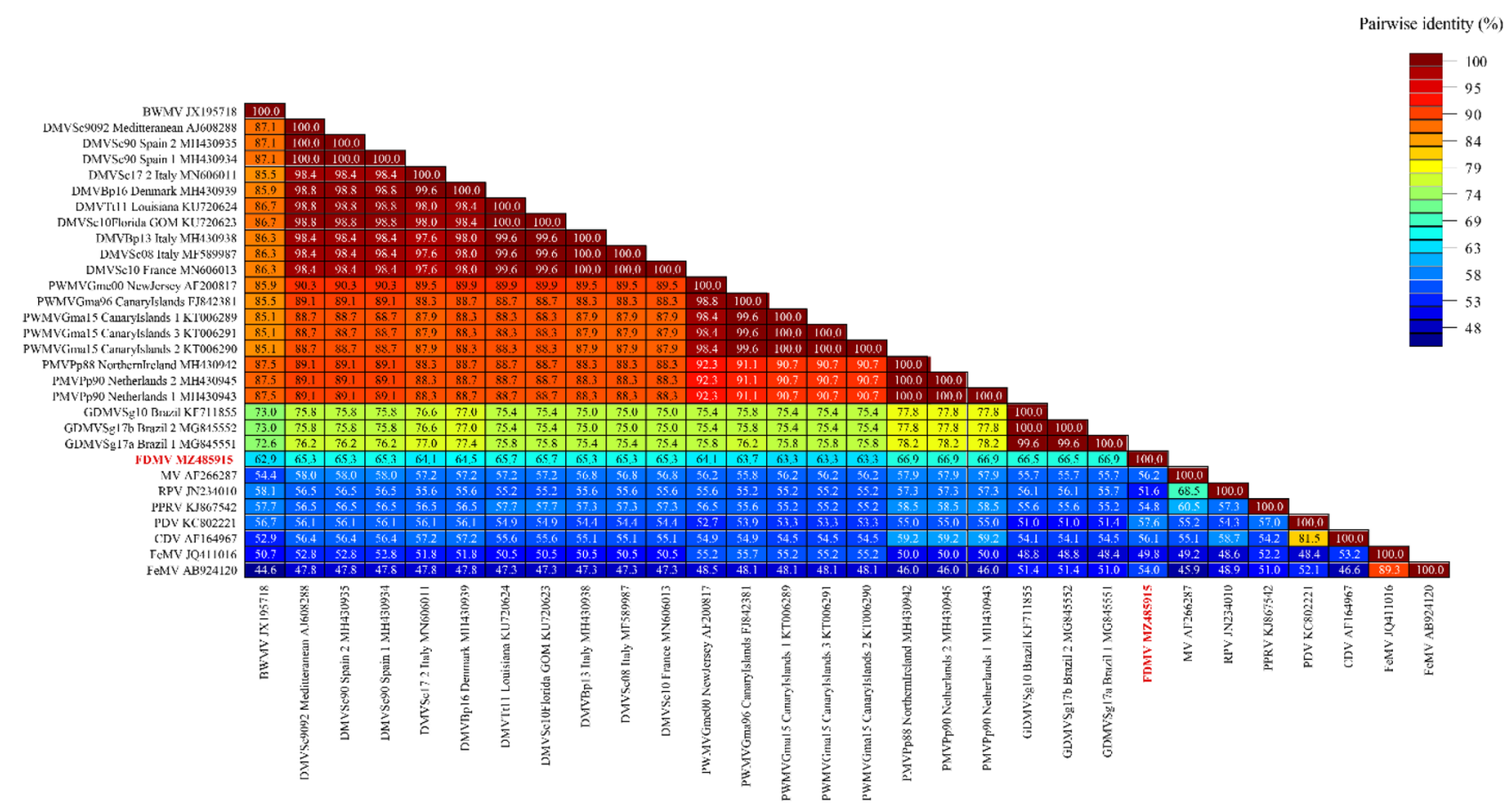

Figure 6. Genetic analysis of 30 partial nucleotide sequences of the $P$ gene. The final data set contained 248 characters including gaps. Values are expressed as a percentage of identity. $B W M V$ beaked whale morbillivirus; FDMV Fraser's dolphin morbillivirus; $P W M V$ pilot whale morbillivirus; $P M V$ porpoise morbillivirus; GDMV Guiana dolphin morbillivirus; $D M V$ dolphin morbillivirus; $M e V$ measles virus; $R P V$ rinderpest virus; $P P R V$ peste-des-petits-ruminants virus; $P D V$ phocine distemper virus; $C D V$ canine distemper virus; FeMV feline morbillivirus.

results were obtained from 10 Fraser's dolphins that mass stranded in Florida in 2003 and PMV seropositive results from 11 of 23 mass stranded Fraser's dolphins in the Gulf of Mexico in 1994 $4^{36,37}$. Additionally, three of four Fraser's dolphins that had stranded in 1997 and 1999 along the coasts of Argentina and Brazil respectively, had antibodies against $\mathrm{DMV}^{38}$. This suggests that morbillivirus is likely endemic in Fraser's dolphins from the Gulf of Mexico and the Southwest Atlantic and it is possible that a novel strain of morbillivirus is similarly circulating among this species in the central Pacific. Fraser's dolphin strandings are extremely rare in Hawaiian waters, with the 2018 individual only the second confirmed stranding of this species in this region. A young Fraser's dolphin was reported dead off Kauai in an advanced state of decomposition in 2004 and a possible newborn Fraser's dolphin was reported dead stranded in $1976^{15}$. With such extreme rarity of stranding, we have not had the opportunity to date to test additional Fraser's dolphins from the central Pacific for the presence of morbillivirus or morbillivirus antibodies.

At this time, the population impact of the novel Fraser's dolphin morbillivirus on this species and the potential impact on other cetacean species inhabiting the central Pacific is unknown. Considering the highly social nature of cetacean groups and that different cetacean species interact, it is probable that the novel Fraser's dolphin morbillivirus could be transmitted to other Hawaiian species. This is especially concerning as many of Hawaii's cetacean stocks are small, island-associated, resident populations that may be particularly vulnerable to any reduction in population size because of an already low number of breeding individuals such as the endangered main Hawaiian Islands insular false killer whale (Pseudorca crassidens), estimated at only 167 individuals ${ }^{39}$. Novel disease is considered a major hurdle to endangered population recovery and even poses the threat of extinction as demonstrated in a recent effort to model the impact of a morbillivirus outbreak on endangered Southern resident killer whales (Orcinus orca) from the Pacific Northwest ${ }^{40}$. Southern resident killer whales were determined to be highly vulnerable to a disease outbreak ${ }^{40}$; similarly, a novel disease outbreak among Hawaii's endangered false killer whale population could have a disastrous impact. Melon-headed whales (Peponocephala electra) in Hawaii are also genetically and behaviorally distinct, with a Kohala resident population of approximately 500 individuals inhabiting shallower waters off the Big Island ${ }^{41}$. Fraser's dolphins have only been sighted six times in Hawaiian waters in over two decades of survey effort, and on four of these occasions, this species was sighted near Hawaii Island with large groups of melon-headed whales and once with pilot whales that were part of the Kona resident stock (Baird, personal communication). The Kohala resident stock of melon-headed whales is frequently sighted interacting with other species of cetaceans, including rough-toothed dolphins (Steno bredanensis) and pilot whales (Globicephala macrorhynchus) that move among the Hawaiian islands and overlap with insular slope cetacean populations, which provides a potential route for widespread transmission among Hawaiian cetaceans. Spotted dolphins (Stenella attenuata), spinner dolphins (Stenella longirostris longirostris) and bottlenose dolphins (Tursiops truncatus) in Hawaiian waters have also been recognized as discrete population stocks $s^{42-45}$ and evidence suggests that rough-toothed dolphins, Cuvier's beaked whales (Ziphius cavirostris), Blainville's beaked whales 


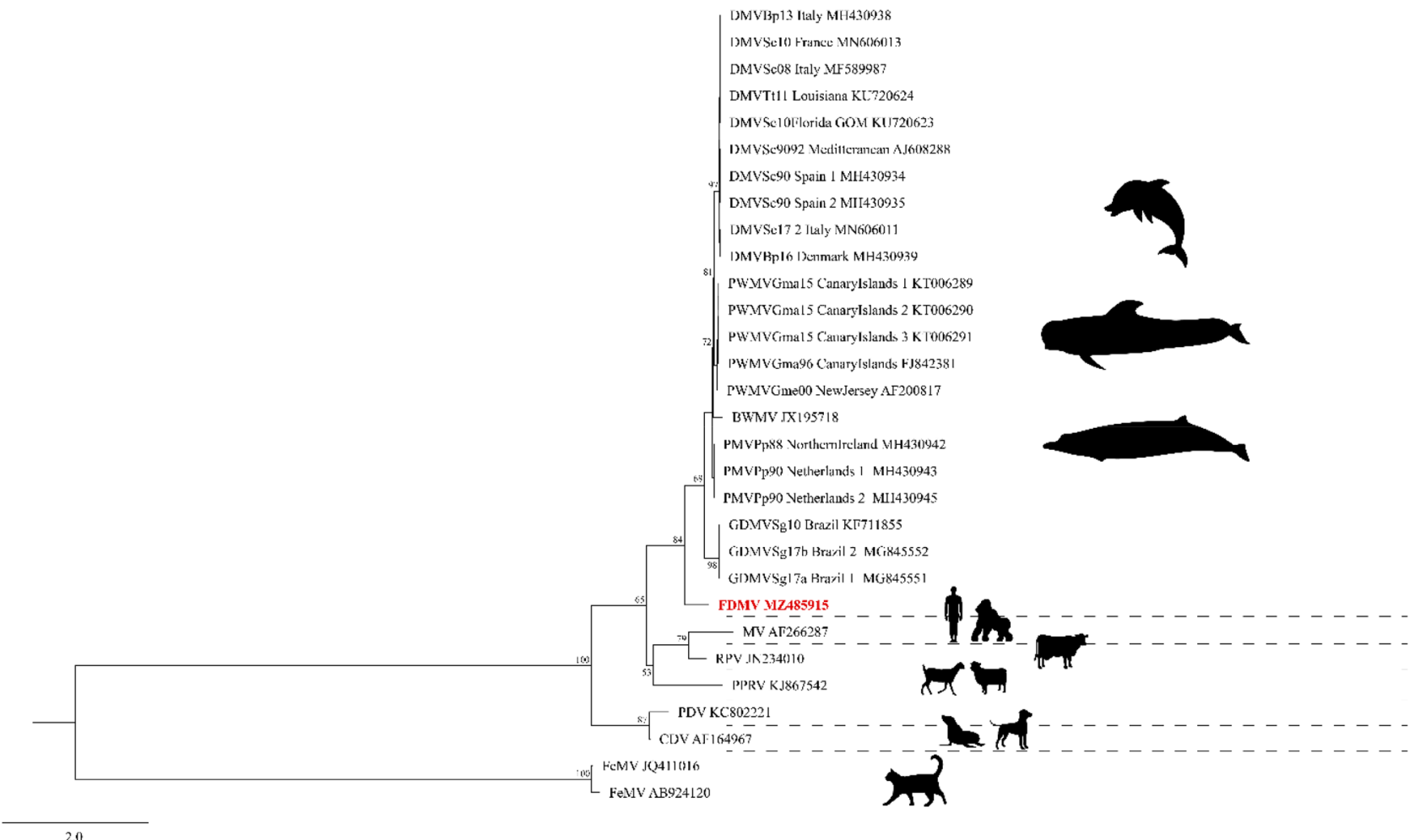

Figure 7. Maximum Likelihood (ML) phylogenetic analysis based on the partial nucleotide (nt) sequences of the $P$ gene. Each sequence is denoted by its strain/isolate name, geographic area of stranding (where available), and GenBank accession number (where available). The phylogeny includes 30 nucleotide sequences with a total of 248 characters (including gaps) in the final dataset. IQ-TREE software (http://iqtree.cibiv.univie.ac.at/) was used to determine best-fit models and perform ML phylogenetic analysis with 1000 non-parametric bootstraps. The best-fit model for the alignment was TPM2 + G4TPM2u + G4, chosen based on Bayesian Information Criterion. $B W M V$ beaked whale morbillivirus; FDMV Fraser's dolphin morbillivirus; $P W M V$ pilot whale morbillivirus; $P M V$ porpoise morbillivirus; GDMV Guiana dolphin morbillivirus; $D M V$ dolphin morbillivirus; $\mathrm{MeV}$ measles virus; $R P V$ rinderpest virus; $P P R V$ peste-des-petits-ruminants virus; $P D V$ phocine distemper virus; $C D V$ canine distemper virus; FeMV feline morbillivirus.

(Mesoplodon densirostris), pilot whales and pygmy killer whales (Feresa attenuata) additionally represent small island-associated populations ${ }^{46-50}$. The presence of many small resident populations makes Hawaii an especially vulnerable location when considering the potential for disease outbreaks among cetaceans.

A significant challenge in understanding disease impacts and conducting monitoring for disease among Hawaiian cetaceans is that the recovery of cetacean carcasses represents only a very small subset of the animals that are actually dying in the region. Carcass recovery rates of cetaceans that die range between 2 and $25 \%$ from other regions, with the high end of $25 \%$ for coastal California bottlenose dolphins caveated as likely to be much lower for pelagic dolphins ${ }^{51,52}$. In Hawaiian waters, we estimate carcass recovery rates near $5 \%$ for endangered main Hawaiian Islands insular false killer whales and Hawaii Island spinner dolphins where population size and mortality rate estimates are available ${ }^{39,53}$, but expect carcass recovery rates would be substantially lower for a pelagic dolphin such as Fraser's dolphins that are infrequently sighted and even more infrequently strand. Consequently, a true epizootic event in the central Pacific may only be detectable with the most concerted efforts. This emphasizes the importance of encouraging rapid public reporting of cetacean strandings and highlights the value of examining every single carcass. Additionally, CeMV has very recently been identified from the exhaled breath of two humpback whale groups in Brazil using a highly sensitive RT-qPCR method ${ }^{54}$ that could be applied to non-invasively monitor cetacean populations in the Pacific. Continued disease surveillance of cetaceans is a top priority for understanding potential disease outbreaks that threaten to decimate small island-associated populations in Hawaii and elsewhere.

\section{Methods}

Fraser's dolphin stranding and gross necropsy. On January $17^{\text {th }}, 2018$ a stranded Fraser's dolphin was reported dead on the beach near Olowalu, Maui $\left(20.79345^{\circ} \mathrm{N},-156.5811^{\circ} \mathrm{W}\right)$. The carcass was recovered and transported to Oahu for necropsy at the University of Hawaii Health and Stranding Laboratory. The necropsy was conducted on the same day and included morphometrics, stomach content examination for prey identification, external and internal gross examination, internal organ weights and extensive formalin-fixed and frozen tissue collections for histopathology and disease screening. 


\begin{tabular}{|c|c|c|c|c|}
\hline Virus name (virus abbreviation) & Common name & Scientific name & Gene & Accession number \\
\hline $\begin{array}{l}\text { USA Dolphin morbillivirus (DMVTt11_Loui- } \\
\text { siana) } \text { ) }^{28}\end{array}$ & Bottlenose dolphin & Tursiops truncatus & Both & KU720624 \\
\hline $\begin{array}{l}\text { USA Dolphin morbillivirus (DMVSc10Flor- } \\
\text { ida_GOM) }\end{array}$ & Striped dolphin & Stenella coeruleoalba & Both & KU720623 \\
\hline $\begin{array}{l}\text { Denmark Dolphin morbillivirus (DMVBp16_ } \\
\text { Denmark) }\end{array}$ & Fin whale & Balaenoptera physalus & Both & MH430939 \\
\hline $\begin{array}{l}\text { Netherlands Porpoise morbillivirus } \\
\text { (PMVPp90_Netherlands(1)) }\end{array}$ & Harbor porpoise & Phocoena phocoena & Both & MH430943 \\
\hline $\begin{array}{l}\text { Netherlands Porpoise morbillivirus } \\
\text { (PMVPp90_Netherlands(2)) }\end{array}$ & Harbor porpoise & Phocoena phocoena & Both & MH430945 \\
\hline $\begin{array}{l}\text { Spain Dolphin morbillivirus (DMVSc90_ } \\
\text { Spain(1) })^{17}\end{array}$ & Striped dolphin & Stenella coeruleoalba & Both & MH430934 \\
\hline $\begin{array}{l}\text { Spain Dolphin morbillivirus (DMVSc90_ } \\
\text { Spain(2) }{ }^{17}\end{array}$ & Striped dolphin & Stenella coeruleoalba & Both & MH430935 \\
\hline $\begin{array}{l}\text { Italy Dolphin morbillivirus (DMVBp13_ } \\
\text { Italy) }{ }^{17}\end{array}$ & Fin whale & Balaenoptera physalus & Both & MH430938 \\
\hline Italy Dolphin morbillivirus (DMVSc08_Italy) $)^{17}$ & Striped dolphin & Stenella coeruleoalba & Both & MF589987 \\
\hline $\begin{array}{l}\text { Ireland Porpoise morbillivirus (PMVPp88_ } \\
\text { NorthernIreland) })^{17}\end{array}$ & Harbor porpoise & Phocoena phocoena & Both & MH430942 \\
\hline $\begin{array}{l}\text { Mediterranean Dolphin morbillivirus } \\
\text { (DMVSc90-92_Meditteranean) }^{29}\end{array}$ & Striped dolphin & Stenella coeruleoalba & Both & AJ608288 \\
\hline $\begin{array}{l}\text { Brazil Dolphin morbillivirus } \\
\text { (DMVSg17_Brazil) }{ }^{9}\end{array}$ & Guiana dolphin & Sotalia guianensis & $L$ gene & MG845553 \\
\hline $\begin{array}{l}\text { Italy Dolphin morbillivirus } \\
\text { (DMVSc17_Italy(2)) }\end{array}$ & Striped dolphin & Stenella coeruleoalba & Both & MN606011 \\
\hline $\begin{array}{l}\text { France Dolphin morbillivirus } \\
\text { (DMVSc10_France) }\end{array}$ & Striped dolphin & Stenella coeruleoalba & Both & MN606013 \\
\hline $\begin{array}{l}\text { New Jersey Pilot Whale morbillivirus } \\
\text { (PWMVGme00_NewJersey) }^{3}\end{array}$ & Long-finned pilot whale & Globicephalus melas & P gene & AF200817 \\
\hline $\begin{array}{l}\text { Canary Islands Pilot Whale morbillivirus } \\
\text { (PWMVGma96_CanaryIslands) }^{30}\end{array}$ & Short-finned pilot whale & Globicephala macrorhynchus & $P$ gene & FJ842381 \\
\hline $\begin{array}{l}\text { Canary Islands Pilot Whale morbillivirus } \\
\text { (PWMVGma15_CanaryIslands(1) })^{31}\end{array}$ & Short-finned pilot whale & Globicephala macrorhynchus & $P$ gene & KT006289 \\
\hline $\begin{array}{l}\text { Canary Islands Pilot Whale morbillivirus } \\
\text { (PWMVGma15_CanaryIslands(3) })^{31}\end{array}$ & Short-finned pilot whale & Globicephala macrorhynchus & P gene & KT006291 \\
\hline $\begin{array}{l}\text { Canary Islands Pilot Whale morbillivirus } \\
\text { (PWMVGma15_CanaryIslands(2) })^{31}\end{array}$ & Short-finned pilot whale & Globicephala macrorhynchus & $P$ gene & KT006290 \\
\hline $\begin{array}{l}\text { Brazil Dolphin morbillivirus } \\
\text { (GDMVSg10_Brazil) }^{4}\end{array}$ & Guiana dolphin & Sotalia guianensis & $P$ gene & KF711855 \\
\hline $\begin{array}{l}\text { Brazil Dolphin morbillivirus } \\
\text { (GDMVSg17_Brazil(2)) }^{9}\end{array}$ & Guiana dolphin & Sotalia guianensis & $P$ gene & MG845552 \\
\hline $\begin{array}{l}\text { Brazil Dolphin morbillivirus } \\
\text { (GDMVSg17_Brazil(1)) }^{9}\end{array}$ & Guiana dolphin & Sotalia guianensis & $P$ gene & MG845551 \\
\hline $\begin{array}{l}\text { USA Dolphin morbillivirus (BWMVIp10_ } \\
\text { Hawaii) }^{12}\end{array}$ & Longman's beaked whale & Indopacetus pacificus & $L$ gene & MW148597 \\
\hline $\begin{array}{l}\text { USA Dolphin morbillivirus (BWMVIp10_ } \\
\text { Hawaii) }^{6}\end{array}$ & Longman's beaked whale & Indopacetus pacificus & $P$ gene & JX195718 \\
\hline $\begin{array}{l}\text { USA Dolphin morbillivirus (FDMVLh18_ } \\
\text { Hawaii) }^{12}\end{array}$ & Fraser's dolphin & Lagenodelphis hosei & $L$ gene & MW079818 \\
\hline $\begin{array}{l}\text { USA Dolphin morbillivirus (FDMVLh18_ } \\
\text { Hawaii) }\end{array}$ & Fraser's dolphin & Lagenodelphis hosei & $P$ gene & MZ485915 \\
\hline Measles virus (MV) $)^{32}$ & Edmonston vaccine strain & N/A & Both & AF266287 \\
\hline Rinderpest virus $(\mathrm{RPV})^{33}$ & Fusan vaccine strain & $\mathrm{N} / \mathrm{A}$ & Both & JN234010 \\
\hline Peste des petits ruminants virus (PPRV) & Domestic goat & Capra aegagrus hircus & Both & KJ867542 \\
\hline
\end{tabular}

Table 2. Virus names, GenBank accession numbers, target gene and references for the morbilliviruses used in the genetic analysis of the $L$ and $P$ gene.

Prey identification from stomach contents. Cephalopod beaks were identified to the lowest possible taxon using the private reference collection of W.A. Walker and the cephalopod reference collection housed at the Marine Mammal Laboratory, Seattle, Washington. The number of lower beaks present was used to estimate the total number of cephalopod species. Dorsal mantle length and total weights were estimated by measuring lower beak rostral length and then applying the appropriate regression equations. Cephalopod beaks were measured to the nearest $0.1 \mathrm{~mm}$ with either an optical micrometer or Vernier calipers and regression equations from the literature were used to estimate prey size and mass for the cephalopod species present ${ }^{55,56}$. 
Immunohistochemistry. Morbillivirus immunohistochemical (IHC) testing was conducted following an in-house developed diagnostic laboratory protocol, as previously described ${ }^{57}$. Epitope retrieval was done using citrate buffer ( $\mathrm{pH}$ 6.0). Nonspecific binding was blocked with $3 \%$ hydrogen peroxide and a commercially available blocking agent (Power Block, Biogenex, San Ramon, CA). The primary antibody was a mouse monoclonal antibody directed against the nucleoprotein of canine distemper virus (\#CDV-NP, Veterinary Medical Research and Development, Pullman, WA) but known to cross-react with other morbilliviruses, at a final concentration of 1:400. The secondary antibody was biotinylated horse anti-mouse IgG, rat absorbed (Vector Labs, Burlingame, $\mathrm{CA}$ ), and the conjugate Streptavidin-horseradish peroxidase (Dako, Carpinteria, CA). The substrate-chromogen system was 3,3'-diaminobenzidine (DAB) (Dako, Carpinteria, CA). Tissue sections were counterstained with Gill's hematoxylin. Positive control was a CDV-infected formalin-fixed and paraffin embedded Vero cell pellet, while the negative control was similarly treated uninfected Vero cell pellet. Positive and negative controls were included in each IHC run.

Morbillivirus isolation. Signaling lymphocyte activation molecule (SLAM) or CD150 is a member of the $\mathrm{C} 2$ subset of the immunoglobulin superfamily and is expressed on a variety of immune cells from a number of mammalian species. In addition to its function of regulating immune response, it has been shown to be a virus receptor for morbilliviruses. Canine SLAM has been transfected into Vero cells ${ }^{58}$ and this Vero.DogSLAMtag cell line has been used successfully to isolate phocine distemper virus (PDV) from experimentally infected ferrets (Mustela putorius furo) and to significantly reduce the incubation time for propagating CeMV in vitro showing its usefulness for morbillivirus isolation ${ }^{59}$. Therefore, Vero.DogSLAMtag cells were chosen to attempt virus isolation of CeMV from frozen tissues collected at necropsy from the Fraser's dolphin (Table 1). Briefly, tissues were rapidly thawed and two sub samples of approximately $1 \mathrm{~g}$ from each tissue were ground in a mortar and pestle with added silica sand. Dulbecco's modified Eagle's medium/Ham's F-12 (DMEM/F-12) plus penicillin $200 \mathrm{IU} / \mathrm{mL}$, streptomycin $200 \mathrm{mg} / \mathrm{mL}$ and gentamicin $50 \mu \mathrm{g} / \mathrm{mL}$ (Thermo Fisher Scientific, Nepean, Canada); was added to give a $10 \% \mathrm{w} / \mathrm{v})$ suspension. Tubes were centrifuged to remove cellular debris for $10 \mathrm{~min}$. (2060 $\mathrm{X} \mathrm{G}$ ), and $500 \mu \mathrm{l}$ served as inoculum for Vero.DogSLAMtag cells simultaneously seeded into $25 \mathrm{~cm}^{2}$ flasks containing $5.0 \mathrm{~mL}$ DMEM/F-12 with $4 \%$ fetal bovine serum (FBS) to give approximately an $80 \%$ confluence of cells. Cell controls were mock infected with diluent. After $24 \mathrm{~h}$ incubation at $37^{\circ} \mathrm{C}$ the media was removed and DMEM/F-12 without serum was added before being returned to the incubator. Flasks were examined daily for signs of CPE passaged weekly, again to give approximately $80 \%$ confluence, in DMEM/F12 plus $4 \%$ FBS. After $24 \mathrm{~h}$ media was changed to DMEM/F-12 without FBS. This procedure was repeated weekly for 1 month at which time the flasks showing no visible CPE were discarded.

Flasks of cells infected with passage one of the isolate were first harvested at 2 days post-infection, then daily from day six until ten days post-infection encompassing all phases of CPE development from initial syncytial development to total monolayer destruction, then processed for transmission electron microscopy.

Transmission electron microscopy. In order to harvest cells detached from the monolayer and viral particles released into the medium, an amount of primary fixative (modified Karnovsky's, $2 \%$ formaldehyde prepared from paraformaldehyde $+2 \%$ glutaraldehyde in $0.1 \mathrm{M}$ cacodylate buffer $\mathrm{pH} 7.3$ ) equal to that of cell culture medium was added to the flask and left for one hr at room temperature. The liquid was removed, placed in a tube and centrifuged to pellet the cells. Supernatant fluid was removed and the pellet re-suspended in fullstrength fixative. The monolayer in the flask was immediately covered with full strength fixative after the removal of floating cells in fixative and incubated for a further $2 \mathrm{~h}$, again at room temperature. The cells were washed with cacodylate buffer, scraped off, pelleted, resuspended in PBS and shipped overnight on ice-packs to UTMB Pathology Electron Microscopy Laboratory. The pellets were washed in cacodylate buffer and kept overnight in $2 \mathrm{P}+2 \mathrm{G}$ fixative at $4{ }^{\circ} \mathrm{C}$. They were washed in cacodylate buffer, post-fixed in $1 \% \mathrm{OsO}_{4}$ in the same buffer and further processed as described earlier ${ }^{60}$.

Morbillivirus detection by RT-PCR. RNA was extracted from frozen samples (i.e. cerebellum, left lung, liver, spleen, left hilar lymph node, mediastinal lymph node and right pre-scapular lymph node) using a commercial kit RNeasy Mini Kit (QIAGEN, Valencia, CA) according to manufacturer instructions. All samples were tested using a reverse transcription polymerase chain reaction (RT-PCR), which were based on consensus degenerate primers ( $L$ gene) used for the detection of paramyxoviruses that target a conserved region of the RNA dependent RNA polymerase ${ }^{61}$. Briefly, the following steps were used for the RT-PCR: one cycle of $50{ }^{\circ} \mathrm{C}$ for $30 \mathrm{~min}$ for cDNA synthesis and one cycle of $95^{\circ} \mathrm{C}$ for $15 \mathrm{~min}$ for denaturing, followed by 40 amplification cycles of $94{ }^{\circ} \mathrm{C}$ for $1 \mathrm{~min}, 45^{\circ} \mathrm{C}$ (ResMorHen-F1/ResMorHen-R) for $1 \mathrm{~min}, 72{ }^{\circ} \mathrm{C}$ for $1 \mathrm{~min}$, and a final elongation cycle of $72^{\circ} \mathrm{C}$ for $10 \mathrm{~min}$. The PCR products were analyzed on a $1 \%$ agarose gel stained with ethidium bromide. Fragments of the expected size ( $559 \mathrm{bp}$ ) were purified using a QIAquick Gel extraction kit (QIAGEN, Valencia, $\mathrm{CA}$ ) and sequenced in both directions using an ABI 3130 DNA sequencer (Life Technologies, Carlsbad, CA).

The partial $P$ gene was sequenced by designing overlapping pairs of primers that were based on the complete genome sequence of a CeMV previously determined from a Mediterranean striped dolphin (DMVSc9092_Meditteranean; GenBank accession no. AJ608288). RNA samples were subjected to a series of overlapping one-step RT-PCR reactions using a OneStep RT-PCR Kit (QIAGEN, Valencia, CA) as recommended by the manufacturer. The following steps were used for the one-step RT-PCR reactions: one cycle of $50{ }^{\circ} \mathrm{C}$ for $30 \mathrm{~min}$ for cDNA synthesis and one cycle of $95^{\circ} \mathrm{C}$ for $15 \mathrm{~min}$ for denaturing, followed by 40 amplification cycles of $94^{\circ} \mathrm{C}$ for $1 \mathrm{~min}$ for denaturing, annealing (temperature dependent upon the primer pair used) for $1 \mathrm{~min}$, elongation step at $72{ }^{\circ} \mathrm{C}$ for $1 \mathrm{~min}$, and a final elongation step at $72{ }^{\circ} \mathrm{C}$ for $10 \mathrm{~min}$. The PCR products were then subjected to electrophoresis in $1 \%$ agarose gel stained with ethidium bromide. DNA fragments of the expected sizes were 
purified using a QIAquick Gel Extraction Kit (QIAGEN, Valencia, CA) and was sequenced in both directions using an ABI 3130 DNA sequencer (Life Technologies, Carlsbad, CA).

Phylogenetic analysis. The phylogenetic analysis was performed based on the 49 partial nucleotide (nt) sequences of the $\mathrm{P}$ gene. The nt sequences were aligned in MAFFT 7 using default parameters ${ }^{62}$. The final data set contained 248 characters including gaps. Maximum Likelihood (ML) phylogenetic analysis was performed in IQ-TREE version 1.4.4 (http://iqtree.cibiv.univie.ac.at/) with the Bayesian information criterion to determine the best model fit and 1000 non-parametric bootstraps to test the robustness of the clades. The phylogenetic tree was then edited using FigTree v1.4.2 ${ }^{63}$. For the genetic analyses, partial nucleotide sequences of the P (49 morbillivirus sequences with 248 characters including gaps) and L (41 morbillivirus sequences with 559 characters including gaps) genes were compared using the Sequence Demarcation Tool v1.2 ${ }^{64}$ with the MAFFT 7 alignment option implemented.

Received: 25 October 2020; Accepted: 9 July 2021

Published online: 09 August 2021

\section{References}

1. Kennedy, S. et al. Viral distemper now found in porpoises. Nature 336, 21 (1988).

2. Domingo, M. et al. Pathologic and immunocytochemical studies of morbillivirus infection in striped dolphins (Stenella coeruleoalba). Vet. Pathol. 29, 1-10 (1990).

3. Taubenberger, J. K. et al. Molecular genetic evidence of a novel morbillivirus in a long-finned pilot whale (Globicephalus melas). Emerging Infect. Dis. 6, 42-45 (2000).

4. Groch, K. R. et al. Novel cetacean morbillivirus in Guiana dolphin, Brazil. Emerg. Infect. Dis. 20, 511-513 (2014).

5. Stephens, N. et al. Cetacean morbillivirus in coastal Indo-Pacific bottlenose dolphins, Western Australia. Emerg. Infect. Dis. 20, 666-670 (2014).

6. West, K. L. et al. A Longman's beaked whale (Indopacetus pacificus) strands in Maui, Hawaii with first case of morbillivirus in the Central Pacific. Mar. Mamm. Sci. 29, 767-776 (2013).

7. Van Bressem, M. F. et al. Cetacean morbillivirus: current knowledge and future directions. Viruses 6, 5145-5181 (2014).

8. Kemper, C. M. et al. Morbillivirus-associated unusual mortality event in South Australian bottlenose dolphins in largest reported for the Southern Hemisphere. R Soc Open Sci. https://doi.org/10.1098/rsos.160838 (2016).

9. Groch, K. R. et al. Guiana dolphin unusual mortality event and link to cetacean morbillivirus, Brazil. Emerging Infect. Dis. 24, 1349-1354 (2018).

10. Groch, K. R. et al. Cetacean morbillivirus in Southern right whales, Brazil. Transbound. Emerg. Dis. 66, 606-610 (2019).

11. Jacob, J. M., West, K. L., Levine, G., Sanchez, S. \& Jensen, B. A. Initial characterization of the novel beaked whale morbillivirus in Hawaiian cetaceans. Dis. Aquat. Org. 117, 215-227 (2016).

12. Landrau-Giovannetti, N. Detection and characterization of emerging pathogens in stranded cetaceans. University of Florida, PhD dissertation. (2019).

13. Baird, R. W., Webster, D. L., Aschettino, J. M., Schorr, G. S. \& McSweeney, D. J. Odontocete cetaceans around the main Hawaiian Islands: habitat use and relative abundance from small-boat sighting surveys. Aquat. Mamm. 39, 253-269 (2013).

14. Maldini, D., Mazzuca, L. \& Atkinson, S. Odontocete stranding patterns in the main Hawaiian Islands (1937-2002): how do they compare with live animal surveys?. Pac. Sci. 59(1), 55-67 (2005).

15. Fisheries, NOAA. "National Stranding Database Public Access | NOAA Fisheries." NOAA. National. https://www.fisheries.noaa. gov/national/marine-life-distress/national-stranding-database-public-access (2020).

16. McCullough, S. J. et al. Isolation and characterization of a porpoise morbillivirus. Arch Virol. 118, 247-252 (1991).

17. Jo, W. K. et al. Evolutionary evidence for multi-host transmission of cetacean morbillivirus. Emerg. Microbes Infect. 7, 201 (2018).

18. Visser, I. K. et al. Characterization of morbilliviruses isolated from dolphins and porpoises in Europe. J Gen. Virol. 74, 631-641 (1993).

19. Dolar, M. L. L., Walker, W. A., Kooyman, G. L. \& Perrin, W. F. Comparative feeding ecology of spinner dolphins (Stenella longirostris) and Fraser's dolphins (Lagenodelphis hosei) in the Sulu Sea. Mar. Mamm. Sci. 19, 1-19 (2003).

20. dos Santos, R. A. \& Haimovici, M. Cephalopods in the diet of marine mammals stranded or incidentally caught along southeastern and southern Brazil $\left(21-34^{\circ} \mathrm{S}\right)$. Fish. Res. 52, 99-112 (2001).

21. Robison, B. H. \& Craddock, J. E. Mesopelagic fishes eaten by Fraser's dolphin Lagenodelphis hosei. Fish. Bull. 81, 283-289 (1982).

22. Wang, M. C., Shau, K. T., Huang, S. L. \& Chou, L. S. Food partitioning among three sympatric odontocetes (Grampus griseus, Lagenodelphis hosei, and Stenella attenuata). Mar. Mamm. Sci. 28, 143-157. https://doi.org/10.1111/j.1748-7692.2011.00501.x (2012).

23. Di Guardo, G. \& Mazzariol, S. Cetacean morbillivirus-associated pathology: knowns and unknowns. Front. Microbil. 7, 112 (2016).

24. Duignan, P. J., Geraci, J. R., Raga, J. A. \& Calzada, N. Pathology of morbillivirus infection in striped dolphins (Stenella coeruleoalba) from Valencia and Murcia, Spain. Can. J. Vet. Res. 56, 242-248 (1992).

25. Groch, K. R. et al. The pathology of cetacean morbillivirus infection and comorbidities in Guiana Dolphins during an unusual mortality event (Brazil, 2017-2018). Vet. Pathol. 57, 845-857 (2020).

26. West, K. L. et al. Coinfection and vertical transmission of Brucella and morbillivirus in a neonatal sperm whale (Physeter macrocephalus) in Hawaii, USA. J Wildl. Dis. 51, 227-232 (2015).

27. Landrau-Giovannetti, N. et al. Genomic characterization of a novel circovirus from a stranded Longman's beaked whale (Indopacetus pacificus). Virus Res. 277, 197 (2020).

28. Fauquier, D. et al. Evaluation of morbillivirus exposure in cetaceans from the northern Gulf of Mexico 2010-2014. Endanger. Species Res. 33, 211-220 (2017).

29. Rima, B. K., Collin, A. M. J. \& Earle, J. A. P. Completion of the sequence of a Cetacean morbillivirus and comparative analysis of the complete genome sequences of four morbillivirus. Virus Genes 30, 113-119 (2005).

30. Bellièr, E. N. et al. Phylogenetic analysis of a new Cetacean morbillivirus from a short-finned pilot whale stranded in the Canary Islands. Res. Vet. Sci. 90, 324-328 (2011).

31. Sierra, E. et al. Morbillivirus and pilot whale deaths, Canary Islands, Spain, 2015. Emerg. Infect Dis. 22, 740-742 (2016).

32. Parks, C. L. et al. Comparison of predicted amino acid sequences of measles virus strains in the Edmonston vaccine lineage. $J$. Virol. 75, 910-920 (2001).

33. Jeoung, H. Y. et al. Complete genome analysis of three live attenuated Rinderpest virus vaccine strains derived through serial passages in different culture systems. J. Virol. 86, 13115-13116 (2012).

34. de Vries, R. D. et al. Delineating morbillivirus entry, dissemination and airborne transmission by studying in vivo competition of multicolor canine distemper viruses in ferrets. PLoS Pathog. https://doi.org/10.1371/journal.ppat.1006371 (2017). 
35. Cifuentes-Muñoz, N., Dutch, R. E. \& Cattaneo, R. Direct cell-to-cell transmission of respiratory viruses: the fast lanes. PLoS Pathog. https://doi.org/10.1371/journal.ppat.1007015 (2018).

36. Rowles, T. K., Schwacke, L. S., Wells, R. S., Saliki, J. T. \& Hansen, L. Evidence of susceptibility to morbillivirus infection in cetaceans from the United States. Mar. Mamm. Sci. 27, 1-19 (2011).

37. Duignan, P. J. et al. Morbillivirus infection in cetaceans of the western Atlantic. Vet. Microbiol. 44, 241-249 https://doi.org/10. 1016/0378-1135(95)00017-5 (1995).

38. Van Bressem, M. et al. An insight into the epidemiology of dolphin morbillivirus worldwide. Vet. Microbiol. 81, 287-304 (2001).

39. Bradford, A. L. et al. Abundance estimates for management of endangered false killer whales in the main Hawaiian Islands. Endanger. Species Res. 36, 297-313 (2018).

40. Weiss, M. N. et al. Modelling cetacean morbillivirus outbreaks in an endangered killer whale population. Biol. Conserv. https:// doi.org/10.8398/j.biocon.2019.108298 (2020).

41. Aschettino, J. M. et al. Population structure of melon-headed whales (Peponocephala electra) in the Hawaiian Archipelago: evidence of multiple populations based on photo-identification. Mar. Mamm. Sci. 28, 666-689 (2012).

42. Baird, R. W. et al. Population structure of island-associated dolphins: evidence from photo-identification of common bottlenose dolphins (Tursiops truncatus) in the main Hawaiian Islands. Mar. Mamm. Sci. 25, 251-274 (2009).

43. Courbis, S., Baird, R. W., Cipriano, F. \& Duffield, D. Multiple populations of pantropical spotted dolphins in Hawaiian waters. J Hered. 105, 627-641 (2014).

44. Hill, M. C., Oleson, E. M. \& Andrews, K. New island-associated stocks for Hawaiian spinner dolphins (Stenella longirostris longirostris): rationale and new stock boundaries. Pacific Islands Fisheries Science Center, National Marine Fisheries Service, NOAA, Honolulu, HI 96822-2296. Pacific Islands Fisheries Science Center Administrative Report. H-10-04, 12 p. (2010).

45. Martien, K. K. et al. Population structure of island-associated dolphins: evidence from mitochondrial and microsatellite markers for common bottlenose dolphins (Tursiops truncatus) around the main Hawaiian Islands. Mar. Mamm. Sci. 28, E208-E232. https:// doi.org/10.1111/j.1748-7692.2011.00506.x (2012).

46. Baird, R. W. et al. Movements of two satellite-tagged pygmy killer whales (Feresa attenuata) off the island of Hawaii. Mar. Mamm. Sci. 27, 332-337. https://doi.org/10.1111/j.1748-7692.2010.00458.x (2011).

47. Baird, R. W. et al. Open-ocean movements of a satellite-tagged Blainville's beaked whale (Mesoplodon densirostris): evidence for an offshore population in Hawai'i?. Aquat. Mamm. 37, 506-511 (2011).

48. Baird, R. W. et al. Site fidelity and association patterns in a deep-water dolphin: rough toothed dolphins (Steno bredanensis) in the Hawaiian Archipelago. Mar. Mamm. Sci. 24, 535-553 (2008).

49. McSweeney, D. J., Baird, R. W., Mahaffy, S. D., Webster, D. L. \& Schorr, G. S. Site fidelity and association patterns of a rare species: pygmy killer whales (Feresa attenuata) in the main Hawaiian Islands. Mar. Mamm. Sci. 25, 557-572 (2009).

50. McSweeney, D. J., Baird, R. W. \& Mahaffy, S. D. Site fidelity, associations and movements of Cuvier's (Ziphius cavirostris) and Blainville's (Mesoplodon densirostris) beaked whales off the island of Hawai'i. Mar. Mamm. Sci. 23, 666-687 (2007).

51. Carretta, J. V. et al. Recovery rates of bottlenose dolphin (Tursiops truncatus) carcasses estimated from stranding and survival rate data. Mar. Mamm. Sci. 32, 349-362 (2017).

52. Williams, R. et al. Underestimating the damage: interpreting cetacean carcass recoveries in the context of the Deepwater Horizon/BP incident. Conserv. Lett. 4, 228-233 (2011).

53. Tyne, J. A., Pollock, K. H., Johnston, D. W. \& Bejder, L. Abundance and survival rates of the Hawaii Island associated spinner dolphin (Stenella longirostris) Stock. PLoS ONE 9, 132. https://doi.org/10.1371/journal.pone.0086132 (2014).

54. Groch, K. R. et al. Cetacean morbillivirus in Humpback whales' exhaled breath. Transbound. Emerg. Dis. https://doi.org/10.1111/ tbed.13883 (2020).

55. Clarke, M. A Handbook for the Identification of Cephalopod Beaks (Clarendon Press, 1986).

56. Wolff, G. A. A beak key for eight eastern tropical Pacific cephalopod species with relationships between their beak dimensions and size. Fish. Bull. 80, 357-380 (1982).

57. Stone, B. M. et al. Fatal cetacean morbillivirus infection in an Australian offshore bottlenose dolphin (Tursiops truncatus). Aust. Vet. J. 89, 452-457 (2011).

58. Seki, F., Ono, N., Yamaguchi, R. \& Yanagi, Y. Efficient isolation of wild strains of canine distemper virus in Vero cells expressing canine SLAM (CD150) and the adaptability to marmoset B95a cells. J. Virol. 77, 9943-9950 (2003).

59. Nielsen, O., Smith, G., Weingartl, H., Lair, S. \& Measures, L. Use of a SLAM transfected Vero cell line to isolate and characterize marine mammal morbilliviruses using an experimental ferret model. J. Wildl. Dis. 44, 600-611 (2008).

60. Emelianchik, A. et al. Characterization of a novel rhabdovirus isolated from a stranded harbour porpoise (Phocoena phocoena). Virus Res. https://doi.org/10.1016/j.virusres.2019.197742 (2019).

61. Tong, S., Wang Chern, S. W., Li, Y., Pallansch, M. A. \& Anderson, L. J. Sensitive and broadly reactive reverse transcription-PCR assays to detect novel paramyxoviruses. J. Clin. Microbiol. 46, 2652-2658 (2008).

62. Katoh, K. \& Standley, D. M. MAFFT multiple sequence alignment software version 7: improvements in performance and usability. Mol. Biol. Evol. 30, 772-780 (2013)

63. Rambaut, A. FigTree v1. 2.2. Institute of Evolutionary Biology. University of Edinburgh. (2014).

64. Muhire, B. M., Varsani, A. \& Martin, D. P. SDT: a virus classification tool based on pairwise sequence alignment and identity calculation. PLoS ONE 9, e108277 (2014).

\section{Acknowledgements}

We would like to thank the stranding responders, including Cheryl King, for their efforts to recover this Fraser's dolphin, and the necropsy team for maximizing the data and samples obtained from this individual. We are grateful to Robin Baird for insightful discussions on the findings and implications. We thank Dr. Yasuke Yanagi, Department of Virology, Kyushu University, Fukuoka, Japan for providing the Vero.DogSLAM cell line. We are also grateful to Jana Phipps for assistance with manuscript preparation. This work was conducted under NOAA Permit \#18786-03 and funded by the National Marine Fisheries Service John H. Prescott Marine Mammal Rescue Assistance Grant Program award numbers NA18NMF4390058 and NA19NMF4390133.

\section{Author contributions}

K.W. wrote the main manuscript text and K.W., I.S., D.R., O.N., T.W., N.L.G., K.S. and V.P. prepared the figures. K.W. and I.S. prepared Table 1. N.D. coordinated the stranding response on Maui, K.W. and I.S. led the necropsy and W.W. conducted prey identification. I.S., D.R., N.L.G., T.W., S.R., O.N., V.P. and J.S. were involved in analysis or diagnostics of collected tissues. Interpretation was carried out by K.W., I.S., T.W., N.L.G., O.N. and D.R. All authors contributed to the manuscript and approved the submitted version. 


\section{Competing interests}

The authors declare no competing interests.

\section{Additional information}

Correspondence and requests for materials should be addressed to K.L.W.

Reprints and permissions information is available at www.nature.com/reprints.

Publisher's note Springer Nature remains neutral with regard to jurisdictional claims in published maps and institutional affiliations.

(c) (i) Open Access This article is licensed under a Creative Commons Attribution 4.0 International License, which permits use, sharing, adaptation, distribution and reproduction in any medium or format, as long as you give appropriate credit to the original author(s) and the source, provide a link to the Creative Commons licence, and indicate if changes were made. The images or other third party material in this article are included in the article's Creative Commons licence, unless indicated otherwise in a credit line to the material. If material is not included in the article's Creative Commons licence and your intended use is not permitted by statutory regulation or exceeds the permitted use, you will need to obtain permission directly from the copyright holder. To view a copy of this licence, visit http://creativecommons.org/licenses/by/4.0/.

(C) The Author(s) 2021, corrected publication 2021 